\title{
EFFECT OF COMPOST RATES, HUMIC ACID TREATMENTS AND NITROGEN FERTILIZER RATES ON GROWTH AND YIELD OF MAIZE
}

\author{
Attia, A. N. E.* ; \\ M. M. B. Darwich \\ S. A. El-Moursy ${ }^{*}$; G. M. A. Mahgoub ${ }^{\star *}$ and
} "Agronomy Dept., Fac. Agric., Mans. Univ.

"Maize Res. Dept., Field Crops Res. Inst., Agric. Res. Center, Giza.

\begin{abstract}
Two field experiments were carried out at the Experimental Farm of Gemmeiza Agriculture Research Station, Agricultural Research Center, Egypt, during the two growing summer seasons of 2010 and 2011. The main objective of this study was to evaluate the effect of compost rates, humic acid treatments and nitrogen fertilizer rates on growth, grain yield and its components of maize cultivar yellow single cross 166 . Each rate of compost was performed in separate experiment. Every experiment of compost rates was carried out in split plot design with four replications. The main plots were occupied with humic acid treatments. The sub-plots were assigned to nitrogen fertilizer rates. The obvious results of this investigation can be summarized as follows:

Adding $30 \mathrm{~m}^{3}$ compost/fed recorded the highest values of growth traits, grain yield and its attributes in both seasons and their combined. Moreover, applying $15 \mathrm{~m}^{3}$ compost/fed came in the second rank in both seasons and their combined. The lowest values of these characters were obtained by control treatment (without compost) in both seasons and their combined

Soaking seeds before planting in humic acid plus foliar spraying plants with humic acid enhanced maize growth, subsequently produced the highest means grain yield and its attributes in both seasons and their combined. It was followed by soaking seeds before planting in humic acid or foliar spraying plants with humic acid in both seasons and their combined.

There were substantial differences in all studied characters among various studied nitrogen fertilizer rates in both seasons and their combined. Fertilizing maize plants with $120 \mathrm{~kg} \mathrm{~N} / \mathrm{fed}$ produced the highest values of these characters in both seasons and their combined. However, using $60 \mathrm{~kg} \mathrm{~N} / \mathrm{fed}$ was accompanied with the least values of grain yield and its attributes characters in both seasons and their combined, as well as there are many significant effect of the interactions among studied factors on studied characters.

Generally, it can be concluded that organic fertilizing maize plants hybrid S.C. 166 with $30 \mathrm{~m} 3$ compost/fed and soaking seeds plus foliar spraying plants with humic acid at the rate of $1000 \mathrm{ppm}$ in addition mineral fertilizing with 120 or $90 \mathrm{~kg}$ $\mathrm{N} /$ fed in order to maximizing its growth and productivity under the environmental conditions of Gemmeiza district, El-Gharbia Governorate.
\end{abstract}

\section{INTRODUCTION}

Maize is the most important cereal grain after wheat and rice, which providing nutrients for humans and animals. In industrialized countries, a larger proportion of the grain is used as livestock feed and as industrial raw material for food and nonfood uses. In developing countries is used mainly as human food, although its use as animal feed is increasing. In Egypt, maize is 
Attia, A. N. E. et al.

considered as one of the main cereal crops, comes the third after wheat and rice. Therefore, to reduce the imported amount it must be used high yielding varieties and optimum agriculture practices of maize such as using organic fertilization (compost and humic acid) and optimum nitrogen fertilizer levels.

Compost is organic matter that has been decomposed and recycled as a fertilizer and soil amendment. Mona et al. (2008) found that yield components of maize significantly increased with the application of both organic and natural conditioners. Also, they gradually increased by increasing the rates of organic and natural conditioners. Compost mineral extract treatment recorded the highest values of straw and grain yields. El-Moursy, Rasha (2009) revealed that plant height, ear height, ear leaf area, ear length, ear diameter, number of rows/ear, number of grains/row, 100-grain weight and grain yield/fed significantly affected by compost rates $(0,2$ and $4 \mathrm{t} / \mathrm{fed})$ in both seasons. The highest values of these characters were obtained by application of the highest dose of compost $(4 \mathrm{t} / \mathrm{fed})$. Attia et al. (2012) reported that all studied growth characters i.e. plant and ear height and ELA were exerted significant effect as a result of applying organic fertilization treatments (without, FYM and compost) in both seasons. The treatment from organic fertilization which gave the highest values of these characters was applying the compost at the rate of $4 \mathrm{t} / \mathrm{fed}$ as compared with other treatments in both seasons.

Humic acid is water-soluble organic acid naturally present in soil organic matter. It can be recognized that humic substances (HS) have many beneficial effects on soil structure and soil microbial populations as well as increase modify mechanisms involved in plant growth stimulation, cell permeability and nutrient uptake and increasing yield. Mayhew (2004) showed that humic substances may possibly enhance the uptake of minerals through the stimulation of microbiological activity. Pettit (2004) reported that humic substances have a very profound influence on the growth of plant roots. When humic acids and fulvic acids are applied to the soil, enhancement of root initiation and increased root growth. Humic acid added in urea can evidently increase grain yield and $\mathrm{N}$ utilizing rate of maize. According to the yield and $\mathrm{N}$ utilizing rate of maize, $10 \%$ humic acid added in urea is better than other treatments in comprehensive effects. Bakry et al. (2009) recorded that significant increases in maize vegetative growth characters (plant height, and leaf contents of chlorophyll a \& b), ear characters and grain yield (ear length, ear diameter, rows number/ear, grains number/row and grain yield/plot) and grain quality parameters (weight of 100 grains) due to humic acid application (spraying plants with $50 \mathrm{mg} \mathrm{K}$-humate/L three times once every month starting from sowing).

Nitrogen has been found to be most important nutrient for maize production, wherever it is a components of protoplasm, proteins, nucleic acids, chlorophyll and plays. Maize has been recognized as a heavy feeder and uses more of nitrogen than any other nutrient element. Many reports indicated that nitrogen is considered as one among the most affective factors in increasing growth, yield and yield components of maize crop (Arif et al., 2010 ; Soliman and Gharib, 2011 ; Attia et al., 2012 and El-Naggar, Nehal et al., 2012). In spite of mineral fertilizers have a good effect on plant 
productivity. Wopereis et al. (2006) concluded that excess application of nitrogen fertilizer could be accumulated in plant tissues in freely manner, this also affects human health and crop quality. Thus, judicious use of mineral nitrogen fertilizer should be promoted on improvement maize productivity.

Therefore, the main objective of the present work was to study the effect of compost rates, humic acid treatments and nitrogen fertilizer levels on growth, grain yield and its components of maize hybrid yellow single cross 166 under the environmental conditions of Gemmeiza district, El-Gharbia Governorate.

\section{MATERIALS AND METHODS}

Two field experiments were carried out at the Experimental Farm of Gemmeiza Agriculture Research Station, Agricultural Research Center, Egypt, during the two growing summer seasons of 2010 and 2011. The main objective of this study was to evaluate the effect of compost rates, humic acid treatments and nitrogen fertilizer rates on growth, grain yield and its components of maize cultivar yellow single cross 166 .

Each rate of compost $\left(0 \mathrm{~m}^{3} / \mathrm{fed}\right.$ i.e. control treatment, $15 \mathrm{~m}^{3} / \mathrm{fed}$ and $30 \mathrm{~m}^{3} / \mathrm{fed}$ ) was performed in separate experiment. Compost was added to experimental units after plowing and leveling and before ridging. Chemical analysis of compost are presented in Table 1. Every experiment of compost rates was carried out in split plot design with four replications.

Table 1: Chemical analysis of compost in 2010 and 2011 seasons.

\begin{tabular}{|l|c|c|}
\hline \multicolumn{1}{|c|}{ Properties } & 2010 season & 2011 season \\
\hline Weight of $1 \mathrm{~m}^{3}(\mathrm{~kg})$ & 900 & 845 \\
\hline Organic matter \% & 29.17 & 33.7 \\
\hline Organic carbon \% & 16.92 & 19.35 \\
\hline $\mathrm{C} / \mathrm{N}$ ratio & $13.86: 1$ & $11.97: 1$ \\
\hline Moisture \% & 22 & 25.4 \\
\hline EC(ds/m,1:10 water extract) & 5.33 & 4.98 \\
\hline $\mathrm{pH}(1: 10$ water suspension) & 6.86 & 7.06 \\
\hline $\mathrm{N} \%$ & 1.78 & 1.92 \\
\hline $\mathrm{P} \%$ & 1.10 & 1.23 \\
\hline $\mathrm{K} \%$ & 1.30 & 1.12 \\
\hline
\end{tabular}

The main plots were occupied with the following four humic acid treatments; 1- Without humic application (control treatment). 2- Soaking grains before planting in humic acid at the rate of $1000 \mathrm{ppm}$ for 24 hours. 3Foliar spraying plants with humic acid at the rate of $1000 \mathrm{ppm}$ twice after 21 and 35 days from planting. 4- Soaking seeds before planting in humic acid at the rate of $1000 \mathrm{ppm}$ for 24 hours beside foliar spraying plants with humic acid at the rate of $1000 \mathrm{ppm}$ twice after 21 and 35 days from planting.

The sub-plots were assigned to nitrogen fertilizer rates $(60,90$ and $120 \mathrm{~kg} \mathrm{~N} / \mathrm{fed})$. Nitrogen fertilizer in the form of urea $(46.0 \% \mathrm{~N})$ was added at the formerly mentioned rates in two equal portions, one half after thinning (before the first irrigation) and the other half before the second irrigation. 
Attia, A. N. E. et al.

Each experimental basic unit (sub - plot) included six ridges, each of $80 \mathrm{~cm}$ width and $6.0 \mathrm{~m}$ length, resulted an area of $28.8 \mathrm{~m}^{2}$ (1/145.83 fed). The preceding winter crop was wheat (Triticum aestivum vulgare L.) in both seasons.

Soil samples were taken at random from the experimental field area at a depths of $0-20,20-40$ and $40-60 \mathrm{~cm}$ from soil surface before soil preparation to measure the mechanical and chemical soil properties. Results of mechanical and chemical analysis are presented in Table 2.

The experimental field well prepared through two ploughing, leveling, and compacting, ridging and then divided into the experimental units (28.8 $\left.\mathrm{m}^{2}\right)$. Calcium superphosphate $\left(\begin{array}{llll}15.5 & \% & \mathrm{P}_{2} \mathrm{O}_{5}\end{array}\right)$ was applied during soil preparation at the rate of $150 \mathrm{~kg} / \mathrm{fed}$. Potassium sulphate $\left(48 \% \mathrm{~K}_{2} \mathrm{O}\right)$ at the rate of $50 \mathrm{~kg} / \mathrm{fed}$ was applied at the first dose of nitrogen fertilizer.

Maize grains were hand planted in hills $20 \mathrm{~cm}$ apart at the rate of $2-$ 3 grains/hill using dry sowing method (Afeer) on one side of the ridge on $10^{\text {th }}$ and $2^{\text {nd }}$ June in 2010 and 2011 seasons, respectively. The plants were thinned to one plant per hill before the first irrigation. The first irrigation was applied after 18 days from sowing and the following irrigations were applied at 12 days intervals during the growing seasons. Hoeing twice was done for controlling weeds before the first and second irrigations. The other agricultural practices were kept the same as normally practiced in maize fields according to the recommendations of Ministry of Agriculture and Land Reclamation, except for the factors under study.

Table 2: Mechanical and chemical analysis of the experimental field" during 2010 and 2011 seasons.

\begin{tabular}{|c|c|c|c|c|c|c|}
\hline \multirow{3}{*}{ Soil content } & \multicolumn{3}{|c|}{2010 season } & \multicolumn{3}{|c|}{2011 season } \\
\hline & \multicolumn{6}{|c|}{ Depth (cm) } \\
\hline & $0-20$ & $20-40$ & $40-60$ & $0-20$ & $20-40$ & $40-60$ \\
\hline \multicolumn{7}{|l|}{ Mechanical analysis } \\
\hline Coarse sand (\%) & 0.61 & 0.43 & 0.36 & 0.75 & 0.52 & 0.24 \\
\hline Fine sand (\%) & 14.07 & 18.52 & 15.02 & 41.23 & 33.19 & 26.98 \\
\hline Silt (\%) & 41.88 & 37.92 & 41.85 & 41.34 & 31.87 & 36.17 \\
\hline Clay (\%) & 43.49 & 43.13 & 42.77 & 16.68 & 34.42 & 36.61 \\
\hline \multicolumn{7}{|l|}{ Chemical analysis } \\
\hline Organic matter (\%) & 1.04 & 0.83 & 0.36 & 1.01 & 0.81 & 0.47 \\
\hline Available N (ppm) & 42.00 & 40.00 & 51.00 & 60.00 & 51.00 & 54.00 \\
\hline Available P (ppm) & 4.50 & 3.40 & 2.10 & 5.40 & 4.70 & 2.85 \\
\hline Exchangeable K (ppm) & 2.35 & 2.03 & 3.05 & 3.25 & 3.05 & 2.65 \\
\hline $\mathrm{pH}(1: 2.5)$ & 8.10 & 8.00 & 8.15 & 8.25 & 8.10 & 8.15 \\
\hline E.C. (m.mhos/cm at $\left.25 \mathrm{C}^{\circ}\right)$ & 3.55 & 3.60 & 3.42 & 3.03 & 2.51 & 2.80 \\
\hline $\mathrm{Ca}^{++}(\mathrm{mg} / 100 \mathrm{gm})$ & 2.80 & 1.98 & 1.76 & 3.28 & 3.10 & 2.90 \\
\hline $\mathrm{Mg}^{++}$ & 1.05 & 1.03 & 1.01 & 1.90 & 1.73 & 2.92 \\
\hline $\mathrm{Na}^{+}$ & 2.57 & 2.88 & 3.01 & 3.55 & 3.24 & 2.15 \\
\hline $\mathrm{HCO}_{3}{ }^{-}$ & 2.10 & 2.05 & 2.25 & 2.57 & 2.60 & 2.55 \\
\hline $\mathrm{SO}_{4}^{--}$ & 7.30 & 6.75 & 6.25 & 8.25 & 8.65 & 8.70 \\
\hline
\end{tabular}

* Soil and Water Analysis Institute, El-Gemmeiza Lab., Agricultural Research Center (ARC). 
Studied characters:

A- Growth characters:

After 75 days from planting, random samples of five guarded plants were taken at random from one ridge of the remaining four ridges of each sub-plot to determine the following growth characters:

1- Plant height $(\mathrm{cm})$.

3- Ear leaf area $\left(\mathrm{cm}^{2}\right)$.

2- Ear height $(\mathrm{cm})$.

B- Yield and its attributes:

4- Chlorophyll content (SPAD.)

At harvest (after 120 days from planting) random samples of ten guarded plants and ears were taken at random from the remaining two ridges of each sub-plot to determine the following yield and its components:

5- Ear length $(\mathrm{cm})$.

6- Ear diameter $(\mathrm{cm})$.

7- Number of rows/ear.

9- 100-grain weight $(\mathrm{g})$.

8- Number of grains/row.

10- Grain yield (ardab/fed).

All obtained data were statistically analyzed according to the technique of analysis of variance (ANOVA) for the split - plot design to each experiment (compost rates), then combined analysis was done between compost rates experiments and seasons as published by Gomez and Gomez (1984). Least Significant of Difference (LSD) method was used to test the differences between treatment means at $5 \%$ level of probability as described by Snedecor and Cochran (1980).

\section{RESULTS AND DISCUSSION}

\section{I- Effect of compost rates:}

\section{A- Growth characters:}

The obtained results obvious that ear leaf area (in the second season and combined over both seasons), plant and ear height and chlorophyll content in maize leaves (in the first season and combined over both seasons) were significantly affected by compost rates as shown from data in Tables 3 and 4 . The highest values of all growth characters were obtained by treated soil with the highest rate of compost $\left(30 \mathrm{~m}^{3} / \mathrm{fed}\right)$ in both seasons and their combined. Followed by using the intermediate rate of compost $\left(15 \mathrm{~m}^{3} / \mathrm{fed}\right)$ in both seasons and their combined. While, the lowest values of above mentioned characters were resulted from control treatment (without compost) in both seasons and their combined. There was not significant between rate of compost $\left(30 \mathrm{~m}^{3} / \mathrm{fed}\right)$ and the intermediate rate of compost $\left(15 \mathrm{~m}^{3} / \mathrm{fed}\right)$ in combined data. The increases in growth characters due to adding the highest rate of compost may be ascribed to compost contains of microorganisms which fix and release phytohormones, which stimulate plant growth and plant height (Nofal, Fatma et al., 2005). These results are in coincidence with those reported by Ali et al. (2003) and Adejumo et al. (2010) which they recorded that organic manure (compost) improved the physical properties of the soil and increased the supplying of available nutrients to plants.

\section{B- Yield and its attributes :}

All yield and its attributes i.e. ear length, number of grains/row, $100-$ grain weight, grain yield/fed (in both seasons and their combined), ear 
Attia, A. N. E. et al.

diameter and number of rows/ear (in the first season and combined over both seasons) were responded significantly as a result of applying compost rates (Tables 5, 6 and 7). Adding $30 \mathrm{~m}^{3}$ compost/fed recorded the highest values of grain yield and its attributes in both seasons and their combined. Moreover, applying $15 \mathrm{~m}^{3}$ compost/fed came in the second rank in both seasons and their combined. Vice versa, the lowest values of these characters were obtained by control treatment (without compost) in both seasons and their combined. Such superiority of adding 30 or $15 \mathrm{~m}^{3}$ compost/fed in increasing grain yield may be due to the improving action of organic matter on physical, biological and chemical properties of soil. Also, the use of organic matter improved soil organic matter, nitrogen content, $\mathrm{P}_{2} \mathrm{O}_{5}$ concentration, exchangeable cations and apart of $\mathrm{Fe}$ and consequently enhanced plant growth and development as well as grain yield (Ali et al., 2003). The scope of this findings is generally according to those obtained by Osman, Mona et al. (2008), El-Moursy, Rasha (2009) and Adejumo et al. (2010).

\section{II- Effect of humic acid treatments:}

\section{A- Growth characters:}

The effect of humic acid treatments on maize growth characteristics i.e. plant height (in both seasons and their combined), ear height, ear leaf area and chlorophyll content in maize leaves (in the first season and combined over both seasons) was significant as shown from data in Tables 3 and 4. From obtained results, it could be observed that soaking seeds and foliar spraying plants with humic acid produced the highest values of all growth characters in both seasons and their combined. It was followed by soaking maize seeds in humic only or foliar spraying plants with humic acid only without significant differences between them in both seasons and their combined. The lowest values of all growth characters were resulted from control treatment (without humic acid) in both seasons and their combined. This increase in growth characters by humic acid treatments may be due to enhance uptake of macronutrients, such as nitrogen, phosphorus and sulfur and micronutrients, that is, $\mathrm{Fe}, \mathrm{Zn}, \mathrm{Cu}$ and $\mathrm{Mn}$ (Chen et al., 2007) as well as beneficial effects on soil structure, soil microbial populations and increase modify mechanisms involved in plant growth stimulation by increasing elongation of the internodes reflecting increases in plant height. These results were parallel with those reported by Bakry et al. (2009).

\section{B- Yieldand its attributes:}

There was significant effect on grain yield and its attributes characters i.e. ear length, 100 - grain weight, grain yield/fed (in both seasons and their combined), ear diameter, number of rows/ear and number of grains/row (in the first season and combined over both seasons) due to humic acid treatments (Tables 5, 6 and 7). From data it can be observed that, soaking seeds before planting in humic acid at the rate of $1000 \mathrm{ppm}$ for 24 hours plus foliar spraying plants with humic acid at the same rate twice after 21 and 35 days from planting led to enhance maize growth, subsequently produced the highest means grain yield and its attributes as well as grain quality characters in both seasons and their combined. It was followed by soaking seeds before planting in humic acid or foliar spraying plants with 
humic acid in both seasons and their combined. On the other side, the lowest values of these characters were resulted from plants growing without humic acid in both seasons and their combined. The favorable effect of humic acid treatments either soaking, foliar or soaking plus foliar might have been due to its effective role in improvement early maize growth, more dry matter accumulation and stimulated the building of metabolic products that translocated to grains. Moreover, its desirable effects in improvement in plant growth characters such as plant height and ear leaf area which reflected in turn increase in the different yield components such as ear length, ear diameter and 100-grain weight. These findings are in coincidence with those recorded by Chen et al. (2007) and Bakry et al. (2009).

\section{III- Effect of nitrogen fertilizer rates:}

\section{A- Growth characters:}

The obtained data revealed that the effect of nitrogen fertilizer rates on growth characters i.e. plant height, ear height, ear leaf area and chlorophyll content in maize leaves (in the first season and combined over both seasons) was significant as shown from data in Tables 3 and 4. It can be stated that all studied growth characters significantly increased as a result of increasing nitrogen fertilizer rates from 60 up to $120 \mathrm{~kg} \mathrm{~N} / \mathrm{fed}$ and the differences between them were obvious over both seasons. Application the highest rate of nitrogen fertilizer (120 kg N/fed) produced the highest values of growth parameter in both seasons and their combined. Fertilizing maize plants with $90 \mathrm{~kg} \mathrm{~N} / \mathrm{fed}$ came in the second rank after fertilizing with $120 \mathrm{~kg}$ $\mathrm{N} / \mathrm{fed}$ with respect to these characters. However, the lowest values of all growth traits were produced from fertilizing maize plants with $60 \mathrm{~kg} \mathrm{~N} / \mathrm{fed}$ in both seasons and their combined of this investigation. The increase in growth characters associated with increasing nitrogen fertilization may be attributed to the role of nitrogen in enhancement meristematic activity and cell division which caused increase in internodes length, number of internodes and both of them. These results are in harmony with those recorded by Soliman and Gharib (2011).

\section{B- Yield and its attributes:}

From obtained data in Tables 5, 6 and 7, grain yield and its attributes characters i.e. 100 - grain weight, grain yield/fed (in both seasons and their combined), ear length, ear diameter, number of rows/ear and number of grains/row (in the first season and combined over both seasons) were significantly affected by nitrogen fertilizer levels. There were substantial differences in all grain yield and its attributes characters among various studied nitrogen fertilizer rates in both seasons and their combined. Fertilizing maize plants with $120 \mathrm{~kg} \mathrm{~N} / \mathrm{fed}$ produced the highest values of grain yield and its attributes characters in both seasons and their combined. However, using $60 \mathrm{~kg} \mathrm{~N} / \mathrm{fed}$ was accompanied with the least values of grain yield and its attributes characters in both seasons and their combined. It was worthy to mention that $90 \mathrm{~kg} \mathrm{~N} / \mathrm{fed}$ rate arranged between aforementioned nitrogen fertilizer rates with respect their effect on grain yield and its attributes characters in both seasons and their combined. The increase in grain yield because of increasing nitrogen fertilizer rate up to $120 \mathrm{~kg} \mathrm{~N} / \mathrm{fed}$ can be easily ascribed to the role of nitrogen in activating growth of plants, consequently 
Attia, A. N. E. et al.

enhancement yield components (ear dimension, number and weight of grains/ear as well as 100-grain weight) and consequently increasing grain yield per unit area. These results are in compatible with those found by Soliman and Gharib (2011) and El-Naggar, Nehal et al. (2012).

\section{IV- Effect of the interactions among studied factors:}

There are many significant effect of the interactions among studied factors on studied characters as shown from Tables 3, 4, 5, 6 and 7 . We have reported enough the significant interactions on grain yield/fed only.

The interaction between compost rates and humic acid treatments showed significant effect on grain yield over both seasons.( Table 8) The maximum value of grain yield ( $35.77 \mathrm{ardab} / \mathrm{fed}$ ) was obtained from organic fertilizing with $30 \mathrm{~m}^{3}$ compost/fed and soaking seeds plus foliar spraying with humic acid at the rate of $1000 \mathrm{ppm}$ over both seasons. While, control treatment of both factors (without compost and without humic acid) resulted in the lowest value of grain yield ( $30.00 \mathrm{ardab} / \mathrm{fed})$ over both seasons.

The interaction between compost rates and nitrogen fertilizer rates showed significant effect on grain yield over both seasons. ( Table 9) The highest value of grain yield (35.15 ardab/fed) was obtained from organic fertilizing with $30 \mathrm{~m}^{3}$ compost/fed and mineral fertilizing with 120 or $90 \mathrm{~kg}$ $\mathrm{N} / \mathrm{fed}$ over both seasons. While, control treatment of both factors (without compost and $60 \mathrm{~kg} \mathrm{~N} / \mathrm{fed}$ ) resulted in the lowest value of grain yield (29.41 ardab/fed) over both seasons. These results are in line with those stated by Makinde and Ayoola (2010).

The effect of the interaction between humic acid treatments and nitrogen fertilizer rates on grain yield was significant over both seasons. The highest value of grain yield (33.87 or $33.15 \mathrm{ardab} / \mathrm{fed}$ ) was obtained from soaking seeds and foliar spraying plants with humic acid besides mineral fertilizing with 120 or $90 \mathrm{~kg} \mathrm{~N} / \mathrm{fed}$ over both seasons (Table 10). On the other side, the lowest value of grain yield (30.18 ardab/fed) was resulted from plots that not treated with humic acid and fertilizing with $60 \mathrm{~kg} \mathrm{~N} / \mathrm{fed}$ over both seasons.

The effect of the interaction among compost rates, humic acid treatments and nitrogen fertilizer rates on grain yield was significant over both seasons as presented in Table 11. It can be observed that, the highest mean of grain yield (34.89 or 34.58 ardab/fed) was resulted from organic fertilizing with $30 \mathrm{~m}^{3}$ compost/fed and soaking seeds plus foliar spraying with humic acid at the rate of $1000 \mathrm{ppm}$ in addition mineral fertilizing with 120 or $90 \mathrm{~kg}$ $\mathrm{N} / \mathrm{fed}$ over both seasons. However, the difference between previously mentioned interaction treatments and organic fertilizing with $30 \mathrm{~m}^{3}$ compost/fed and soaking seeds plus foliar spraying with humic acid in addition mineral fertilizing with $90 \mathrm{~kg} \mathrm{~N} / \mathrm{fed}$ was insignificant over both seasons. On the other hand, plants growing without compost and humic acid application and mineral fertilizing with $60 \mathrm{~kg} \mathrm{~N} / \mathrm{fed}$ only resulted in the lowest value of grain yield (29.94 ardab/fed) over both seasons. 
Table 3: Plant and ear height of maize as affected by compost rates, humic acid treatments and nitrogen fertilizer rates as well as their interactions during 2010, 2011 and combined over both seasons.

\begin{tabular}{|c|c|c|c|c|c|c|}
\hline \multirow{2}{*}{ Treatments Characters } & \multicolumn{3}{|c|}{$\begin{array}{l}\text { Plant height } \\
\text { (cm) }\end{array}$} & \multicolumn{3}{|c|}{$\begin{array}{l}\text { Ear height } \\
\text { (cm) }\end{array}$} \\
\hline & 2010 & 2011 & Combined & 2010 & 2011 & Combined \\
\hline \multicolumn{7}{|l|}{ A- Compost rates: } \\
\hline Without compost (control) & $r \leqslant V, V$ & $T \leqslant Y, T \leqslant$ & $r \leq 0,1$ & $1 \leqslant 9$, & $T \leq \varepsilon, V$ & $1 \leqslant 7,9$ \\
\hline $15 \mathrm{~m}^{3} / \mathrm{fed}$ & YOY,Y & $r \leqslant \Psi, T \leqslant$ & $r \leqslant V, q$ & $10 \mathrm{~V}, 7$ & $1 \leqslant \varepsilon, \Gamma$ & $101,$. \\
\hline $30 \mathrm{~m}^{3} / \mathrm{fed}$ & $Y 00,1$ & $T \leqslant r, \Lambda T$ & $r \leqslant 9,1$ & $10 \mathrm{~V}, 7$ & $1 \leq 7,1$ & 10r,. \\
\hline F. test & * & NS & * & * & NS & * \\
\hline LSD at $5 \%$ & $T, Y$ & - & $r,$. & $r, r$ & - & $Y, Y$ \\
\hline \multicolumn{7}{|l|}{ B- Humic acid treatments: } \\
\hline Without humic (control) & $r \leqslant 9, V$ & $r \leqslant 1, \ldots$ & $T \leqslant 0, \varepsilon$ & $104, Y$ & $1 \leqslant \Gamma, 9$ & $1 \leqslant \Lambda, 7$ \\
\hline Soaking in humic & YOY, $\varepsilon$ & $r \leqslant r, \Lambda$. & $r \leqslant \Lambda, 1$ & $10 \leq, 9$ & $1 \leqslant \varepsilon, \lambda$ & $1 \leqslant 9,9$ \\
\hline Foliar spraying with humic & rol, & $r \leqslant r, V \cdot$ & $T \leqslant V, \varepsilon$ & $100,$. & $1 \leqslant 0, \varepsilon$ & $10 \cdot, Y$ \\
\hline Soaking + Foliar spraying & To\&,V & $r \leqslant 0,$. & $r \leqslant 9,1$ & 100,9 & $1 \leqslant 7, \Gamma$ & 101,1 \\
\hline F. test & $\star$ & * & * & * & NS & * \\
\hline LSD at $5 \%$ & $Y, V$ & $r, 7$ & $r, Y$ & 1.9 & - & 1,1 \\
\hline \multicolumn{7}{|l|}{ C- Nitrogen fertilizer rates: } \\
\hline $60 \mathrm{~kg} \mathrm{~N} / \mathrm{fed}$ & $r \leqslant 9, r$ & $r \leqslant \Gamma, \Gamma$ & $r \leqslant 7, r$ & $10 \leqslant,$. & $1 \leqslant 0, r$ & $1 \leq 9,7$ \\
\hline $90 \mathrm{~kg} \mathrm{~N} / \mathrm{fed}$ & 101,1 & $r \leq r, \varepsilon$ & $r \leqslant V, T$ & $10 \leqslant, V$ & $1 \leqslant 0,0$ & $10 \cdot, 1$ \\
\hline $120 \mathrm{~kg} \mathrm{~N} / \mathrm{fed}$ & $T \circ \varepsilon, 7$ & $r \leq T, T$ & $r \leqslant 9, \cdot$ & $10 \mathrm{~V}, \mathrm{Y}$ & $1 \leq 7$, & 101,7 \\
\hline F. test & * & NS & * & * & NS & * \\
\hline LSD at $5 \%$ & 1,9 & - & 1,7 & $1, \mathrm{~V}$ & - & 1,7 \\
\hline \multicolumn{7}{|l|}{ C- Interactions: } \\
\hline A X B & * & NS & * & * & NS & * \\
\hline$A \times C$ & * & * & * & * & NS & NS \\
\hline $\mathrm{B} \times \mathrm{C}$ & 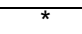 & * & NS & * & NS & NS \\
\hline $\mathrm{A} \times \mathrm{B} \times \mathrm{C}$ & * & NS & 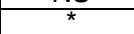 & * & NS & NS \\
\hline
\end{tabular}

Table 4: Ear leaf area (ELA) and chlorophyll content in maize leaves as affected by compost rates, humic acid treatments and nitrogen fertilizer rates as well as their interactions during 2010, 2011 and combined over both seasons.

\begin{tabular}{|c|c|c|c|c|c|c|}
\hline \multirow{2}{*}{ Treatments Characters } & \multicolumn{3}{|c|}{$\operatorname{ELA}\left(\mathrm{cm}^{2}\right)$} & \multicolumn{3}{|c|}{ Chlorophyll content (SPAD) } \\
\hline & 2010 & 2011 & $\begin{array}{c}\text { Combine } \\
\text { d }\end{array}$ & 2010 & 2011 & $\begin{array}{c}\text { Combine } \\
\text { d }\end{array}$ \\
\hline \multicolumn{7}{|l|}{ A- Compost rates: } \\
\hline Without compost (control) & $V \leqslant \Gamma, 0$ & $\nabla O \Lambda, Y$ & $\mathrm{VO} \cdot, \lambda$ & $0 \leqslant, \lambda$. & $7 \cdot, 1 \mathrm{~V}$ & $0 \mathrm{~V}, 0 \mathrm{~V}$ \\
\hline $15 \mathrm{~m}^{3} / \mathrm{fed}$ & VIT,Y & 879,9 & Vา7, & 07,71 & $7 \cdot, Y 7$ & $0 \wedge, 19$ \\
\hline $30 \mathrm{~m}^{3} / \mathrm{fed}$ & $V \lambda I, V$ & $\mathrm{Vq \cdot ,V}$ & $\nabla \wedge 0, \lambda$ & $07, V Y$ & $7 \cdot, T Y$ & $01,0 Y$ \\
\hline F. test & NS & * & * & * & NS & * \\
\hline LSD at $5 \%$ & - & $\Lambda, r$ & 9,1 & $1, Y T$ & - & $\cdot, 94$ \\
\hline \multicolumn{7}{|l|}{ B- Humic acid treatments: } \\
\hline Without humic (control) & VIT,T & VTT,T & VTY, 9 & $00, \Gamma \leqslant$ & 09,17 & OV, ro \\
\hline Soaking in humic & V7r, & $\nabla \wedge I, r$ & $V V Y, q$ & 07,10 & $7 \cdot, 1 Y$ & $0 \wedge, 1 T$ \\
\hline Foliar spraying with humic & $V 7 \varepsilon, 7$ & $\nabla \wedge \varepsilon, Y$ & $V V T, q$ & $0 \leqslant, 94$ & 7., $\varepsilon$. & $0 V, 77$ \\
\hline Soaking + Foliar spraying & $\mathrm{V} 91, \mathrm{~V}$ & $\lambda \cdot V, Y$ & $\Lambda \cdot r, q$ & $0 \wedge, \leqslant Y$ & $7 \cdot, 7 Y$ & $09,0 Y$ \\
\hline F. test & & NS & & $\bar{*}$ & NS & $\neq$ \\
\hline LSD at $5 \%$ & $\Lambda, \varepsilon$ & - & 11,1 & $1, \Gamma \wedge$ & - & $1,1 \leqslant$ \\
\hline \multicolumn{7}{|l|}{ C- Nitrogen fertilizer rates: } \\
\hline $60 \mathrm{~kg} \mathrm{~N} / \mathrm{fed}$ & $\vee 71, \cdot$ & $\vee \wedge 0, \Sigma$ & $V \vee T, Y$ & 00,70 & $09,0 Y$ & $0 V, 0 \wedge$ \\
\hline $90 \mathrm{~kg} \mathrm{~N} / \mathrm{fed}$ & V7T, & V9६, $\varepsilon$ & $\nabla \vee q, \cdot$ & 07,11 & $7 \cdot, 1 Y$ & $0 \wedge, 11$ \\
\hline $120 \mathrm{~kg} \mathrm{~N} / \mathrm{fed}$ & $\nabla \wedge I, \wedge$ & $\Lambda \cdot \varepsilon, 9$ & VqY,r & 07,91 & $7 \cdot, \leq 7$ & 01,79 \\
\hline F. test & * & NS & 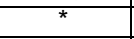 & * & NS & * \\
\hline LSD at $5 \%$ & $\Lambda, \cdot$ & - & $1 \cdot, \cdot$ & $1, \cdot r$ & - & $\cdot, \Lambda T$ \\
\hline \multicolumn{7}{|l|}{ C- Interactions: } \\
\hline$A \times B$ & * & NS & NS & * & NS & * \\
\hline $\mathrm{A} \times \mathrm{C}$ & * & NS & NS & * & NS & NS \\
\hline $\mathrm{BXC}$ & * & NS & NS & * & NS & NS \\
\hline$A \times B \times C$ & NS & NS & NS & * & NS & NS \\
\hline
\end{tabular}


Attia, A. N. E. et al.

Table 5: Ear length and diameter of maize as affected by compost rates, humic acid treatments and nitrogen fertilizer rates as well as their interactions during 2010, 2011 and combined over both seasons.

\begin{tabular}{|c|c|c|c|c|c|c|}
\hline Characters & & length & m) & & amet & $(\mathrm{cm})$ \\
\hline Treatments & 2010 & 2011 & Combined & 2010 & 2011 & Combined \\
\hline A- Compost rates: & & & & & & \\
\hline Without compost (control) & $r \cdot, \cdot \Lambda$ & Y1,00 & $r \cdot, \lambda$ & $\varepsilon, Y T$ & $\varepsilon, V Y$ & $\varepsilon, \varepsilon V$ \\
\hline $15 \mathrm{~m}^{3} / \mathrm{fed}$ & $Y \cdot, \sum T$ & $Y Y, Y \leq$ & YI, ro & $\varepsilon, 49$ & $\varepsilon, V Y$ & $\varepsilon, 00$ \\
\hline $30 \mathrm{~m}^{3} / \mathrm{fed}$ & $r \cdot, V I$ & Yr,, 9 & YI, 9. & $\varepsilon, 0 V$ & $\varepsilon, \sqrt{ } 0$ & $\varepsilon, 77$ \\
\hline F. test & & * & * & 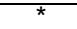 & NS & 7 \\
\hline LSD at $5 \%$ & $\cdot, \leqslant 9$ & $\cdot, \pi$ & $\cdot, Y_{9}$ & $\cdot, 11$ & - & $\cdot, \cdot 9$ \\
\hline B- Humic acid treatments & & & & & & \\
\hline Without humic (control) & $Y_{\cdot}, r_{\bullet}$ & YI, Y $\leq$ & $Y \cdot, V Y$ & $\varepsilon, 10$ & $\varepsilon, V$. & $\varepsilon, \varepsilon \Gamma$ \\
\hline Soaking in humic & $r \cdot, 01$ & rY, TY & $r 1, \leqslant T$ & $\varepsilon, \varepsilon \Gamma$ & $\varepsilon, V \varepsilon$ & $\varepsilon, 01$ \\
\hline Foliar spraying with humic & Y.,YT & $r Y, Y \wedge$ & 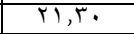 & $\varepsilon, \Gamma \wedge$ & $\varepsilon, V \varepsilon$ & $\varepsilon, 07$ \\
\hline Soaking + Foliar spraying & $r \cdot, T r$ & $r Y, \Gamma \wedge$ & $T 1,0$. & 4.64 & $\varepsilon, \vee 0$ & $\varepsilon, 79$ \\
\hline F. test & * & * & * & * & NS & * \\
\hline LSD at $5 \%$ & $\cdot$, ro & $\cdot, r^{9}$ & $\cdot, T Y$ & $\cdot, 1$ & - & 0.10 \\
\hline C- Nitrogen fertilizer rates & & & & & & \\
\hline $60 \mathrm{~kg} \mathrm{~N} / \mathrm{fed}$ & $r \cdot, r T$ & TY, YO & 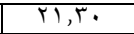 & $\varepsilon, T Y$ & $\varepsilon, V Y$ & $\varepsilon, O Y$ \\
\hline $90 \mathrm{~kg} \mathrm{~N} / \mathrm{fed}$ & $r \cdot, \varepsilon \cdot$ & $r Y, Y \wedge$ & YI,T & $\varepsilon, \Gamma V$ & $\varepsilon, V \Gamma$ & $\varepsilon, 00$ \\
\hline $120 \mathrm{~kg} \mathrm{~N} / \mathrm{fed}$ & 21.10 & TY,TE & $T, V Y$ & $\varepsilon, 01$ & $\varepsilon, V \varepsilon$ & $\varepsilon, 7\}$ \\
\hline F. test & * & NS & * & * & NS & * \\
\hline LSD at $5 \%$ & 0.42 & - & 0.38 & $\cdot, 11$ & - & $\cdot, \cdot 7$ \\
\hline C- Interactions: & & & & & & \\
\hline$A \times B$ & * & NS & NS & NS & NS & NS \\
\hline$A \times C$ & * & NS & NS & NS & NS & NS \\
\hline $\mathrm{B} \times \mathrm{C}$ & * & NS & NS & NS & NS & NS \\
\hline $\mathrm{A} \times \mathrm{B} \times \mathrm{C}$ & * & NS & & NS & NS & NS \\
\hline
\end{tabular}

Table 6: Number of rows/ear and number of grains/row of maize as affected by compost rates, humic acid treatments and nitrogen fertilizer rates as well as their interactions during 2010, 2011 and combined over both seasons.

\begin{tabular}{|c|c|c|c|c|c|c|}
\hline \multirow{2}{*}{ Treatments Characters } & \multicolumn{3}{|c|}{ Number of rows/ear } & \multicolumn{3}{|c|}{ Number of grains/row } \\
\hline & 2010 & 2011 & Combined & 2010 & 2011 & Combined \\
\hline \multicolumn{7}{|l|}{ A- Compost rates: } \\
\hline Without compost (control) & $\mid \leqslant, \leqslant 1$ & 10,01 & $1 \leqslant, 97$ & $\varepsilon \leqslant, 10$ & $\varepsilon V, Y O$ & $\leqslant 7, .0$ \\
\hline $15 \mathrm{~m}^{3} / \mathrm{fed}$ & $1 \leqslant, 07$ & 10,11 & $10, Y Y$ & $\leqslant 0, \leqslant 0$ & $\varepsilon \Lambda, 0 Y$ & $\sum 7,91$ \\
\hline $30 \mathrm{~m}^{3} / \mathrm{fed}$ & TE,9T & $10,9$. & $\mid 0, \varepsilon 1$ & $\varepsilon 7, \Gamma T$ & $\varepsilon 9, \ldots$ & $\sum V, T V$ \\
\hline F. test & * & NS & * & * & * & * \\
\hline LSD at $5 \%$ &., 10 & - & $\cdot, 10$ & $\cdot, \wedge \wedge$ & $\cdot, 91$ & $\cdot, \lambda 1$ \\
\hline \multicolumn{7}{|l|}{ B- Humic acid treatments: } \\
\hline Without humic (control) & 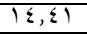 & 10,11 & 10,11 & $\varepsilon \leqslant, Y \leqslant$ & $\leq V, \leq \leqslant$ & $\leqslant 0, \wedge \leqslant$ \\
\hline Soaking in humic & $|\leq| V \mid$, & 10,11 & 10,19 & $\leqslant 0,0$ & $\sum \Lambda, \cdot Y$ & $\sum 7,0 Y$ \\
\hline Foliar spraying with humic & $1 \varepsilon, 7 Y$ & $10,1 \mathrm{~V}$ & $10, Y \leq$ & $\leqslant 7,10$ & $\varepsilon \Lambda, 0 \Lambda$ & $\sum V, \Gamma \uparrow$ \\
\hline Soaking + Foliar spraying & $1 \varepsilon, V V$ & 10,9 & $10, T T$ & $\varepsilon V, \cdot \varepsilon$ & $\varepsilon \Lambda, 7 \Gamma$ & $\varepsilon \vee, \wedge \varepsilon$ \\
\hline F. test & * & NS & * & * & NS & * \\
\hline LSD at $5 \%$ & $\cdot, 1 T$ & - & $\cdot, 11$ & $\cdot, 79$ & - & $\cdot, \varepsilon \cdot$ \\
\hline \multicolumn{7}{|l|}{ C- Nitrogen fertilizer rates: } \\
\hline $60 \mathrm{~kg} \mathrm{~N} / \mathrm{fed}$ & $1 \leq, 0 r$ & $10,1 Y$ & $10,1 \mathrm{~V}$ & $\varepsilon \varepsilon, \wedge V$ & $\left.\sum \vee,\right\rceil \wedge$ & $\varepsilon \neg, Y \wedge$ \\
\hline $90 \mathrm{~kg} \mathrm{~N} / \mathrm{fed}$ & $1 \leqslant, 7$ & $10,1 \varepsilon$ & $10, Y Y$ & $\sum 0,7 V$ & $\varepsilon \wedge, 1 \leqslant$ & $\sum V, 0$ \\
\hline $120 \mathrm{~kg} \mathrm{~N} / \mathrm{fed}$ & $T \varepsilon, V Y$ & 10,91 & $10, T Y$ & $\varepsilon 7,0 \mathrm{~V}$ & $\varepsilon \Lambda, \varepsilon \Gamma$ & $\sum V, \Gamma \uparrow$ \\
\hline F. test & * & NS & * & * & NS & * \\
\hline LSD at $5 \%$ & $\cdot, 11$ & - & $\cdot, \cdot 9$ & $\cdot, \leq 9$ & - & $\cdot, T Y$ \\
\hline \multicolumn{7}{|l|}{ C- Interactions: } \\
\hline $\mathrm{AXB}$ & * & NS & NS & * & NS & * \\
\hline $\mathrm{AXC}$ & * & NS & NS & * & NS & * \\
\hline $\mathrm{B} \times \mathrm{C}$ & * & NS & NS & * & NS & * \\
\hline $\mathrm{A} \times \mathrm{B} \times \mathrm{C}$ & * & NS & NS & * & NS & * \\
\hline
\end{tabular}


Table 7: 100-grain weight and grain yield/fed of maize as affected by compost rates, humic acid treatments and nitrogen fertilizer rates as well as their interactions during 2010, 2011 and combined over both seasons.

\begin{tabular}{|c|c|c|c|c|c|c|}
\hline \multirow{2}{*}{\begin{tabular}{|l} 
Characters \\
Treatments
\end{tabular}} & \multicolumn{3}{|c|}{ 100-grain weight $(\mathrm{g})$} & \multicolumn{3}{|c|}{ Grain yield (ardab/fed) } \\
\hline & 2010 & 2011 & Combined & 2010 & 2011 & Combined \\
\hline \multicolumn{7}{|l|}{ A- Compost rates: } \\
\hline Without compost (control) & ro, l. & $r 0,10$ & $r_{0, \varepsilon \Lambda}$ & $r \cdot, r$ & $\Gamma, .0$ & $\Gamma \cdot, \tau$ \\
\hline $15 \mathrm{~m}^{3} / \mathrm{fed}$ & $r \uparrow, \varepsilon \cdot$ & 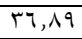 & rT,70 & TI, YO & $\Gamma 1,90$ & זו, T. \\
\hline $30 \mathrm{~m}^{3} / \mathrm{fed}$ & $r V, T \Lambda$ & $r \wedge, 17$ & $r V, q Y$ & rY,qT & $\Gamma 0,97$ & $\Gamma \varepsilon, \varepsilon \varepsilon$ \\
\hline F. test & * & * & * & * & * & * \\
\hline LSD at $5 \%$ & $\cdot, r_{0}$ & $\cdot, \varepsilon 1$ & $\cdot, v \leqslant$ & $\cdot, 94$ & $1, \cdot r$ & $\cdot, 97$ \\
\hline \multicolumn{7}{|l|}{ B- Humic acid treatments: } \\
\hline Without humic (control) & ro, rT & ry, ro & $r 0, v q$ & $r q, 7 V$ & TY,10 & $r \cdot, 91$ \\
\hline Soaking in humic & ru, ro & $r 4,9 r$ & MY, TE & $M, 0 \leqslant$ & $r r, 99$ & ru,V. \\
\hline Foliar spraying with humic & $r 7,9$. & $M V, Y Y$ & $r V, \cdot T$ & $r \cdot, 91$ & Tr,AY & $r, \varepsilon \wedge$ \\
\hline Soaking + Foliar spraying & $r 4,9 r$ & $r V, r \wedge$ & $r v, 10$ & $r 1,01$ & $r \varepsilon,+7$ & $M T, V T$ \\
\hline F. test & * & * & * & * & * & * \\
\hline LSD at $5 \%$ & $\cdot, \varepsilon Y$ & $\cdot, 09$ & $\cdot, \varepsilon \Gamma$ & $1, \cdot Y$ & $1, \cdot 1$ & $1, \cdot \varepsilon$ \\
\hline \multicolumn{7}{|l|}{ C- Nitrogen fertilizer rates: } \\
\hline $60 \mathrm{~kg} \mathrm{~N} / \mathrm{fed}$ & $r 0, r_{T}$ & ro, vo & $r 0,01$ & $r \cdot, \varepsilon \wedge$ & $\Gamma 1,0 \leqslant$ & $\Gamma 1, \cdot 1$ \\
\hline $90 \mathrm{~kg} \mathrm{~N} / \mathrm{fed}$ & $r 4,0 \leq$ & $r v, \ldots$ & $r y, V V$ & rI, r & $r r, \cdot q$ & Tr, Y. \\
\hline $120 \mathrm{~kg} \mathrm{~N} /$ fed & MT,VO & $r v, 17$ & 17,90 & $r Y, \Sigma Y$ & $\Gamma \varepsilon, 01$ & 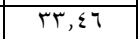 \\
\hline F. test & * & * & * & * & * & * \\
\hline LSD at $5 \%$ & $\cdot, \mu$ & $\cdot, 19$ & $\cdot, r \cdot$ & $\cdot$, vo & $\cdot$, Vo &., $0 T$ \\
\hline \multicolumn{7}{|l|}{ C- Interactions: } \\
\hline$A \times B$ & * & * & * & * & * & * \\
\hline $\mathrm{A} \times \mathrm{C}$ & * & NS & NS & * & * & * \\
\hline $\mathrm{B} \times \mathrm{C}$ & * & NS & * & * & * & * \\
\hline$A \times B \times C$ & * & * & * & * & * & * \\
\hline
\end{tabular}

Table 8: Grain yield of maize as affected by the interaction between compost rates and humic acid treatments over both seasons.

\begin{tabular}{|l|c|c|c|c|}
\hline \multicolumn{1}{|c|}{ Compost rates } & \multicolumn{4}{|c|}{ Humic acid treatments } \\
\cline { 2 - 5 } & $\begin{array}{c}\text { Without humic } \\
\text { (control) }\end{array}$ & $\begin{array}{c}\text { Soaking in } \\
\text { humic }\end{array}$ & $\begin{array}{c}\text { Foliar } \\
\text { spraying with } \\
\text { humic }\end{array}$ & $\begin{array}{c}\text { Soaking + } \\
\text { Foliar } \\
\text { spraying }\end{array}$ \\
\hline Without compost (control) & 30.00 & 30.77 & 30.21 & 30.71 \\
\hline $15 \mathrm{~m}^{3} / \mathrm{fed}$ & 30.64 & 31.32 & 32.06 & 32.81 \\
\hline $30 \mathrm{~m}^{3} / \mathrm{fed}$ & 32.00 & 34.66 & 35.25 & 35.77 \\
\hline F. test & \multicolumn{4}{|c|}{0.97} \\
\hline LSD at $5 \%$ & \multicolumn{4}{|c|}{} \\
\hline
\end{tabular}

Table 9: Grain yield of maize as affected by the interaction between compost rates and nitrogen fertilizer rates over both seasons.

\begin{tabular}{|l|c|c|c|}
\hline \multirow{2}{*}{\multicolumn{1}{|c|}{ Compost rates }} & \multicolumn{3}{c|}{ Nitrogen fertilizer rates } \\
\cline { 2 - 4 } & $\mathbf{6 0} \mathbf{~ k g ~ N / f e d ~}$ & $\mathbf{9 0} \mathbf{~ k g ~ N / f e d ~}$ & $\mathbf{1 2 0} \mathbf{~ k g ~ N / f e d ~}$ \\
\hline Without compost (control) & 29.41 & 30.66 & 31.83 \\
\hline $15 \mathrm{~m}^{3} / \mathrm{fed}$ & 30.20 & 33.41 & 33.41 \\
\hline $30 \mathrm{~m}^{3} / \mathrm{fed}$ & 33.41 & 35.15 & 35.15 \\
\hline F. test & \multicolumn{3}{|c|}{0.96} \\
\hline LSD at 5\% & \multicolumn{3}{|c|}{} \\
\hline
\end{tabular}


Attia, A. N. E. et al.

Table 10: Grain yield of maize as affected by the interaction between compost rates and nitrogen fertilizer rates over both seasons.

\begin{tabular}{|l|c|c|c|}
\hline \multirow{2}{*}{ Humic acid treatments } & \multicolumn{3}{c|}{ Nitrogen fertilizer rates } \\
\cline { 2 - 4 } & $\mathbf{6 0} \mathbf{~ k g ~ N / f e d ~}$ & $\mathbf{9 0} \mathbf{~ k g ~ N / f e d ~}$ & $\mathbf{1 2 0} \mathbf{~ k g ~ N / f e d ~}$ \\
\hline Without humic (control) & 30.18 & 30.01 & 32.54 \\
\hline Soaking in humic & 31.08 & 32.99 & 33.59 \\
\hline Foliar spraying with humic & 31.08 & 32.59 & 33.78 \\
\hline Soaking + Foliar spraying & 31.70 & 33.15 & 33.87 \\
\hline F. test & \multicolumn{3}{|c|}{0.95} \\
\hline LSD at 5\% & \multicolumn{3}{|c|}{} \\
\hline
\end{tabular}

Table 11: Grain yield of maize as affected by the interaction among compost rates, humic acid treatments and nitrogen fertilizer rates over both seasons.

\begin{tabular}{|c|c|c|c|c|}
\hline \multirow{2}{*}{ Compost rates } & \multirow{2}{*}{ Humic acid treatments } & \multicolumn{3}{|c|}{ Nitrogen fertilizer rates } \\
\hline & & $60 \mathrm{~kg} \mathrm{~N} / \mathrm{fed}$ & $90 \mathrm{~kg} \mathrm{~N} / \mathrm{fed}$ & $120 \mathrm{~kg} \mathrm{~N} / \mathrm{fed}$ \\
\hline \multirow{4}{*}{$\begin{array}{l}\text { Without compost } \\
\text { (control) }\end{array}$} & Without humic (control) & 29.94 & 30.07 & 32.09 \\
\hline & Soaking in humic & 30.41 & 30.46 & 32.43 \\
\hline & Foliar spraying with humic & 30.56 & 32.49 & 32.49 \\
\hline & Soaking + Foliar spraying & 30.37 & 33.29 & 33.31 \\
\hline \multirow{4}{*}{$15 \mathrm{~m}^{3} / \mathrm{fed}$} & Without humic (control) & 30.05 & 30.40 & 32.06 \\
\hline & Soaking in humic & 30.54 & 31.63 & 33.83 \\
\hline & Foliar spraying with humic & 32.52 & 32.49 & 33.27 \\
\hline & Soaking + Foliar spraying & 32.74 & 33.63 & 34.31 \\
\hline \multirow{4}{*}{$30 \mathrm{~m}^{3} / \mathrm{fed}$} & Without humic (control) & 30.21 & 31.03 & 32.17 \\
\hline & Soaking in humic & 31.51 & 32.92 & 34.79 \\
\hline & Foliar spraying with humic & 31.66 & 33.44 & 34.87 \\
\hline & Soaking + Foliar spraying & 31.72 & 34.58 & 34.89 \\
\hline \multicolumn{2}{|l|}{ F. test } & \multicolumn{3}{|c|}{ * } \\
\hline \multicolumn{2}{|l|}{ LSD at $5 \%$} & \multicolumn{3}{|c|}{1.42} \\
\hline
\end{tabular}

\section{REFERENCES}

Adejumo, S.A. ; A.O. Togun ; J.A. Adediran and M.B. Ogundiran (2010). Effects of compost application on remediation and the growth of maize planted on lead contaminated soil. $19^{\text {th }}$ World Cong. of Soil Sci., Soil Solutions for a Changing World 1-6 August 2010, Brisbane, Australia.(C.F. Computer Search)

Ali, K.M.L. ; Wafaa, .T. El-Etr and Elham, I. El-khatib (2003). Evaluation of application of bacterial inoculation for rice straw during compost process under aerobic conditions. J. Agric. Sci. Mansoura Univ., 28: 5787-5801.

Arif, M. ; M.T Jan ; N.U. Khan ; H. Akbar ; S.A. Khan ; M.J. Khan ; A. Khan ; I. Munir ; M. Saeed and A. Iqbal (2010). Impact of plant populations and nitrogen levels on maize. Pakistan J. Bot., 42(6): 3907-3913.

Attia, A.N. ; S.A. El-Moursy ; E.M. Said ; S.E. Seadh and A.A.S. El-Azab (2012). Response of maize growth to organic and foliar fertilization under nitrogen fertilizer levels. J. Plant Production, Mansoura Univ., 3(6): 1063-1074. 
Bakry, M.A.A. ; Y.R.A. Soliman and Samir A.M. Moussa (2009). Importance of micronutrients, organic manure and biofertilizer for improving maize yield and its components grown in desert sandy soil. Res. J. of Agric. and Biol. Sci., 5(1): 16-23.

Chen, Y. ; C.E. Clapp ; H. Magen and V.W. Cline (2007). Stimulation of plant growth by humic substances: Effects on iron availability. In: Ghabbour, EA, Davies G. (eds.), Understanding humic substances: Advanced methods, properties and applications. Royal Society of Chemistry, Cambridge, UK. pp: 255-263. .(C.F. Computer Search).

El-Moursy, Rasha S.A. (2009). Effect of plant population, organic fertilization and nitrogen levels on growth and yield of maize. M.Sc. Thesis, Fac. of Agric. Mansoura Univ., Egypt.

El-Naggar, Nehal Z. A. ; M. A. Mohamed; S. A. Mowafy and I. M. Abd El-Hameed (2012). Effect of FYM and N fertilizer on yield and land use efficiency of maize - soybean intercropping. J. Plant Production, Mansoura Univ., 3 (5): $729-746$.

Gomez, K.N. and A.A. Gomez (1984). Statistical procedures for agricultural research. John Wiley and Sons, New York, 2 nd ed., 68 p.

Makinde, E.A. and O.T. Ayoola (2010). Growth, yield and NPK uptake by maize with complementary organic and inorganic fertilizers. American Journal of Food Agriculture Nitration and Development, AJFAND, 10(3): 2203-2217.

Mayhew, L. (2004). Humic substances in biological agriculture [Online]. Available at www. acresusa.com /toolbox/reprints/Jan04_Humic \% 20 Substances.pdf (2004). .(C.F. Computer Search)

Nofal, Fatma, A.E.; M.S.M. Soliman and M.M. Abdel-Ghani (2005). Effect of irrigation at different water depletions levels, nitrogen and manure applications on water use efficiency and maize grain yield in sandy soils. Menufiya J. Agric. Res., 30(1): 1159-1177.

Osman, Mona, A. ; Wafaa, M.A. Seddik and Gehan H. Youssef (2008). Effect of some organic and natural conditioners addition on physical and chemical properties of soil, its nutrient status and Zea mays yield. J. Agric. Sci. Mansoura Univ., 33 (12): 9183-9194.

Pettit, R.E. (2004). Organic matter, humus, humate, humic acid, fulvic acid and humin: their importance in soil fertility and plant health [Online]. Available at www.humate.info/mainpage.htm. C.F. Computer Search)

Snedecor, G. W. and W. G. Cochran (1980). Statistical Methods, 7th Ed., Ames, IA: The lowa State University Press.

Soliman, I.E. and H.S. Gharib (2011). Response of weeds and maize (Zea mays L.) to some weed control treatments under different nitrogen fertilizer rates. Zagazig J. Agric. Res., 38 (2): 249-271.

Wopereis, M.C.S. ; A. Tamelokpo ; K. Ezui ; D. Gnakpenou ; B. Fofana and $\mathrm{H}$. Breman (2006). Mineral fertilizer management of maize on farmer differing in organic inputs in the West African savanna. Field Crops Res., 96: 355-362. 
Attia, A. N. E. et al.

تأثير معدلات الكومبوست ومعاملات حمض الهيومك ومعدلات السماد النيتروجينى

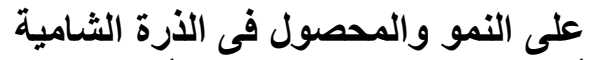

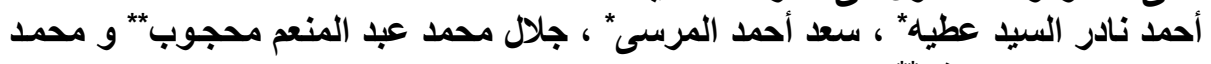

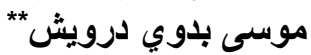

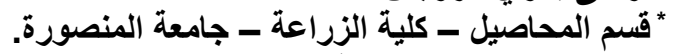
** قشم بحوث الذّرة الثُامية ، معهل بحوث المحة المحاصيل الحقلية ، مركز البحوث الزراعية بالجيزة.

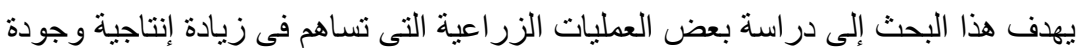

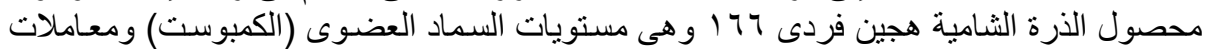

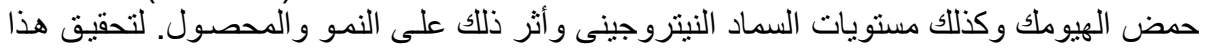

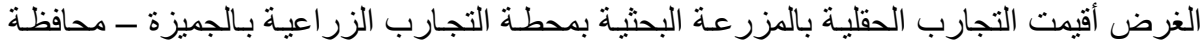

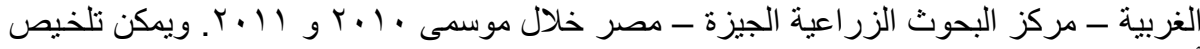

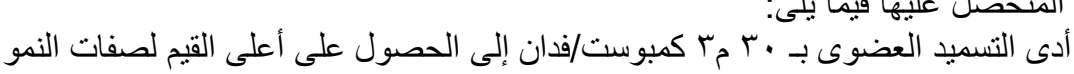

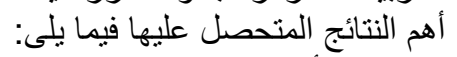

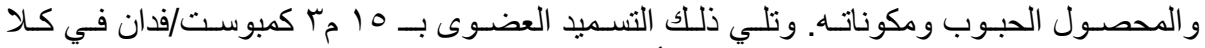

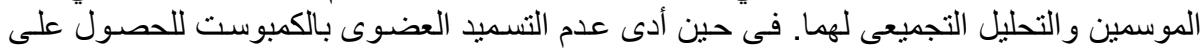

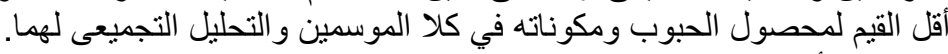

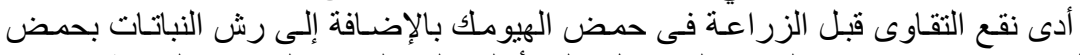

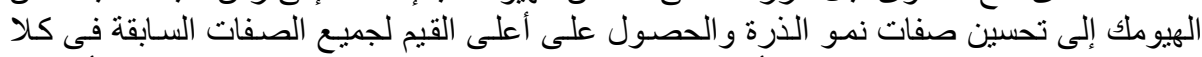

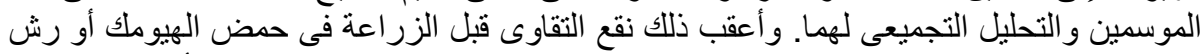

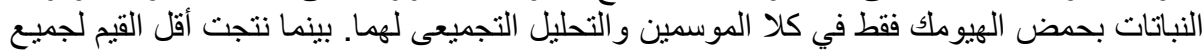
صفات النمو تحت الدراسة من معاملة المقارنة (بدون حمض الهين الهيوملك) في كلا الموسمين و التحليل

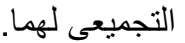

أدى التسميد النيتروجينى بمعدل • ب ا كجم نيتروجين/فدان إلى الحصول على أعلى القيم

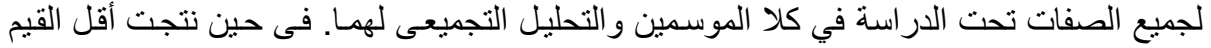

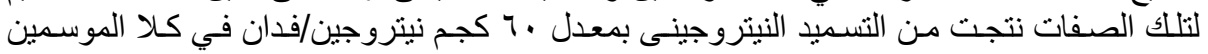
و التحليل التجميعى لهما.

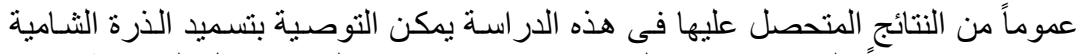

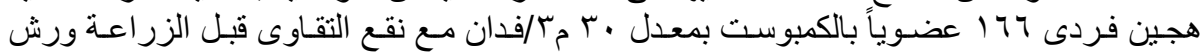

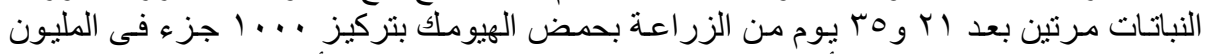

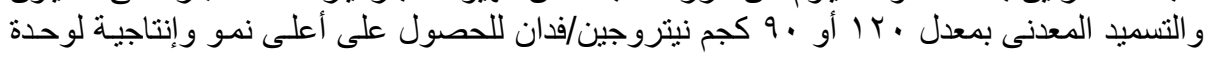
المساحةة تحت ظروف منطقة الجميزة - محافظة الغربية.

كلية الزراعة - جامعة المنصورة مركز البحوث الزراعية

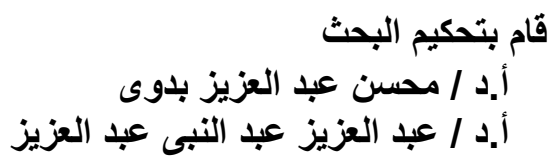

قام بتحكيم البحث أ.د / عبد العزيز عبد النبى عبد العزيز لدوى 